Article

\title{
Correlation among Antioxidant, Antimicrobial, Hemolytic, and Antiproliferative Properties of Leiothrix spiralis Leaves Extract
}

\section{Marcelo Gonzaga de Freitas Araújo ${ }^{1, *}$, Felipe Hilário ${ }^{2}$, Wagner Vilegas ${ }^{2}$, Lourdes Campaner dos Santos ${ }^{2}$, Iguatemy Lourenço Brunetti ${ }^{3}$, Claudia Elena Sotomayor ${ }^{4}$ and Tais Maria Bauab ${ }^{1}$}

1 Biological Sciences Department, Faculty of Pharmaceutical Sciences, São Paulo State University_UNESP, Araraquara, SP 14801-902, Brazil; E-Mail: tmbauab@fcfar.unesp.br

2 Organic Chemistry Department, Chemistry Institute, São Paulo State University-UNESP, c.p. 355, Araraquara, SP 14800-900, Brazil; E-Mails: felipehilario1e6@hotmail.com (F.H.); vilegasw@gmail.com (W.V.); loursant@iq.unesp.br (L.C.S.)

3 Clinical Analysis Department, Faculty of Pharmaceutical Sciences, São Paulo State University_UNESP, Araraquara, SP 14801-902, Brazil; E-Mail: brunetti@fcfar.unesp.br

4 Department of Clinical Biochemistry, CIBICI-CONICET, Faculty of Chemical Sciences, National University of Cordoba, Haya de la Torre y Medina Allende, Córdoba 5000, Argentina; E-Mail: csotomay@fcq.unc.edu.ar

* Author to whom correspondence should be addressed; E-Mail: mgfaraujo@yahoo.com.br; Tel.: +55-16-3301-4670; Fax: +55-16-3301-6940.

Received: 20 April 2012; in revised form: 15 July 2012 / Accepted: 20 July 2012 / Published: 24 July 2012

\begin{abstract}
The biological activities of a plant extract depend on a complex sum of individual properties including the antioxidant activity. Several biological activities protect against the harmful action of reactive oxygen species (ROS), and here we focused our attention on the relationship between the biological activities tested and the antioxidant properties. In this study, the total flavonoid content as well as the antioxidant, antimicrobial, hemolytic and cytotoxicity activities of the methanolic extract of Leitothrix spiralis leaves were evaluated. The extract showed a total flavonoid content of $19.26 \%$ and the chemical characterization by HPLC-PAD confirmed the presence of flavonoids as the major secondary metabolite compounds. Significant antioxidant activity $\left(\mathrm{IC}_{50}=1.743 \mu \mathrm{g} / \mathrm{mL} \pm 0.063\right)$ was demonstrated and was effective against Gram-negative organisms and all Candida strains tested, and showed an ability to inhibit hyphal formation. Non-hemolytic and antiproliferative activity could be demonstrated.
\end{abstract}


Keywords: Leiothrix spiralis; luteolin; antioxidant; antimicrobial; hemolytic; citotoxicity

\section{Introduction}

Reactive oxygen species (ROS) and reactive nitrogen species (RNS), including free radicals such as superoxide radical anion, hydroxyl radicals, singlet oxygen, hydrogen peroxide and nitric oxide are continuously produced in human cells [1,2]. In this sense, natural products have been attracting scientific interest due to their antioxidant and chemopreventive properties. It is well-known that one of the main characteristics responsible for the antioxidant activity of a plant extract is its high content of phenolic compound and its ability to scavenge free radicals, which can play a part in the protection against the harmful action of ROS. Phenolic compounds also exhibit a wide range of other biological effects, such as anti-viral, antibacterial, and anti-tumor [3-7].

Oxidative stress is now recognized as a major factor associated with the development of chronic diseases, including cancer and cardiovascular disease. This has led to the hypothesis that the beneficial effects of natural products could be largely explained by their high content of antioxidants [8,9]. Alterations in the regulation of a number of key pathways in controlling cell proliferation are necessary for the establishment of all tumors. Several antioxidants in plants have been suggested to contribute to the anticarcinogenic effect, and others such as flavanols have also been able to inhibit cancer cell proliferation in vitro [10].

Leiothrix, a Eriocaulaceae genus, is exclusively found in South America of which 37 species are mainly restricted to Brazil. Some species of this family are of great economic importance since they are exported as ornamental plants to various countries, mainly Germany and Japan [11]. Chemical studies of the contents of soluble phenolic compounds of Leiothrix species were performed and the presence of xanthones and flavones, including nepetin-7-O- $\beta$-D-glucopyranoside, nepetin-7-O- $\beta$-D-arabinopyranoside and luteolin $O$ - and $C$-glucopyranoside, rutin, 6-methoxyapigenin-7-O- $\beta$-D-glucopyranoside and 6-methoxyapigenin, were identified [5,12-14]. Antimicrobial activity of phenolic compounds from Leiothrix spiralis was investigated, showing activity on different strains of bacteria and yeasts [15]. Interest in natural antioxidant sources prompted us to investigate the biological activity of $L$. spiralis.

Although many studies concerning the antioxidant activity of plant extracts have been performed, only a few have tried to correlate this activity with antimicrobial and antiproliferative properties. Thus, the aim of the present study was to chemically characterize and quantify total flavonoids in the methanolic extract of $L$. spiralis leaves, as well as to evaluate its antioxidant, antimicrobial, hemolytic and human cancer cell antiproliferative activities. 


\section{Results and Discussion}

\subsection{Chemical Characterization}

The characterization of analytes was based on the comparison of the UV spectra of the peaks (Figure 1). With PAD (Photodiodo Array Detector) scanning from 200-600 nm, it was possible to obtain the UV spectra of each peak, which permitted the selection of a suitable wavelength in order to maximize the detection of the constituents. According to their corresponding UV absorbance, a wavelength of $254 \mathrm{~nm}$ was determined to be the most appropriate to ensure maximum detection for the simultaneous analyses of all compounds present. The UV spectra of the peaks corroborated the presence of flavone derivatives (peaks 1 to 7 with bands at 239-270 nm and 327-349 nm) [16] (Figure 2).

Figure 1. HPLC-PAD (Photodiodo Array Detector) chromatogram recorded at $254 \mathrm{~nm}$ of the methanolic extract of leaves from L. spiralis. For chromatographic conditions see Experimental section.

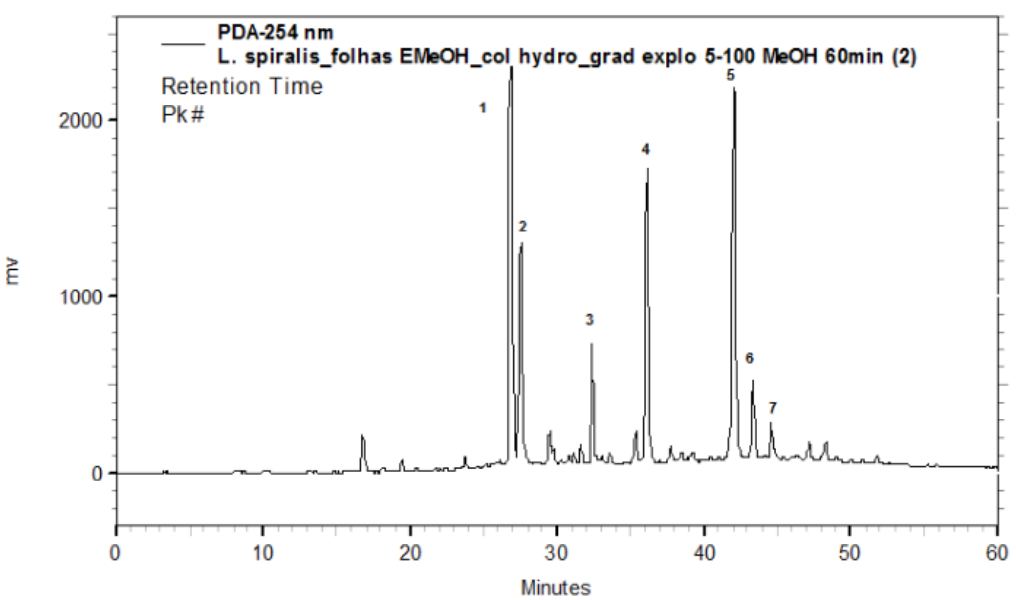

Figure 2. UV spectra of the chromatographic (HPLC) data of the methanolic extract of leaves from L. spiralis (peaks 1-7). Conditions: Phenomenex Synergi Hydro RP18 $(250 \times 4.6 \mathrm{~mm}$ i.d.; $4 \mu \mathrm{m})$ equipped with a Phenomenex security guard column $(4.0 \times 2.0 \mathrm{~mm}$ i.d. $)$. The mobile phase composition was methanol. The gradient program was as follows: $5 \%-100 \% \mathrm{MeOH}$ in $60 \mathrm{~min}$. The flow rate was $1.0 \mathrm{~mL} / \mathrm{min}$ and the total run time was $60 \mathrm{~min}$.

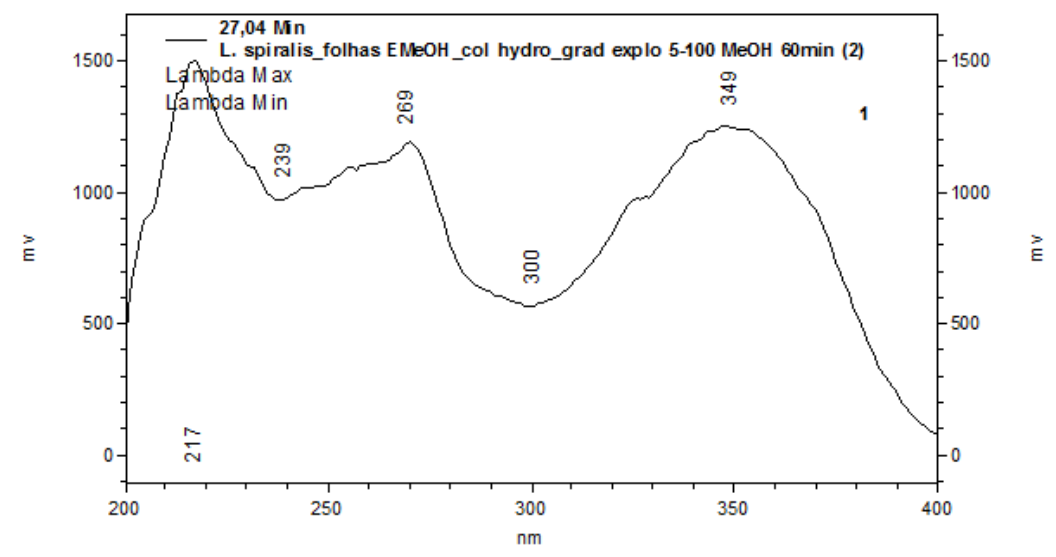


Figure 2. Cont.
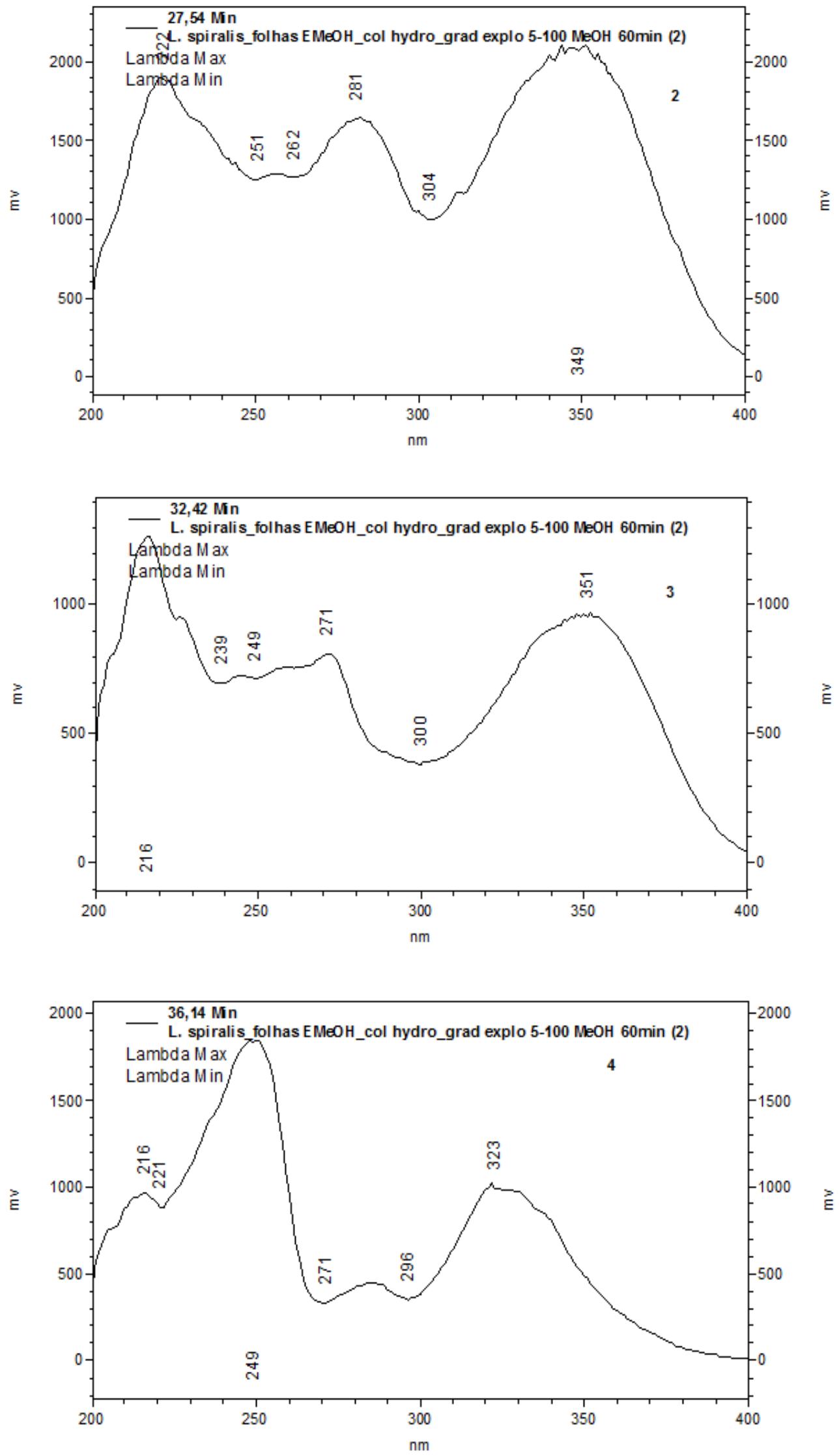
Figure 2. Cont.
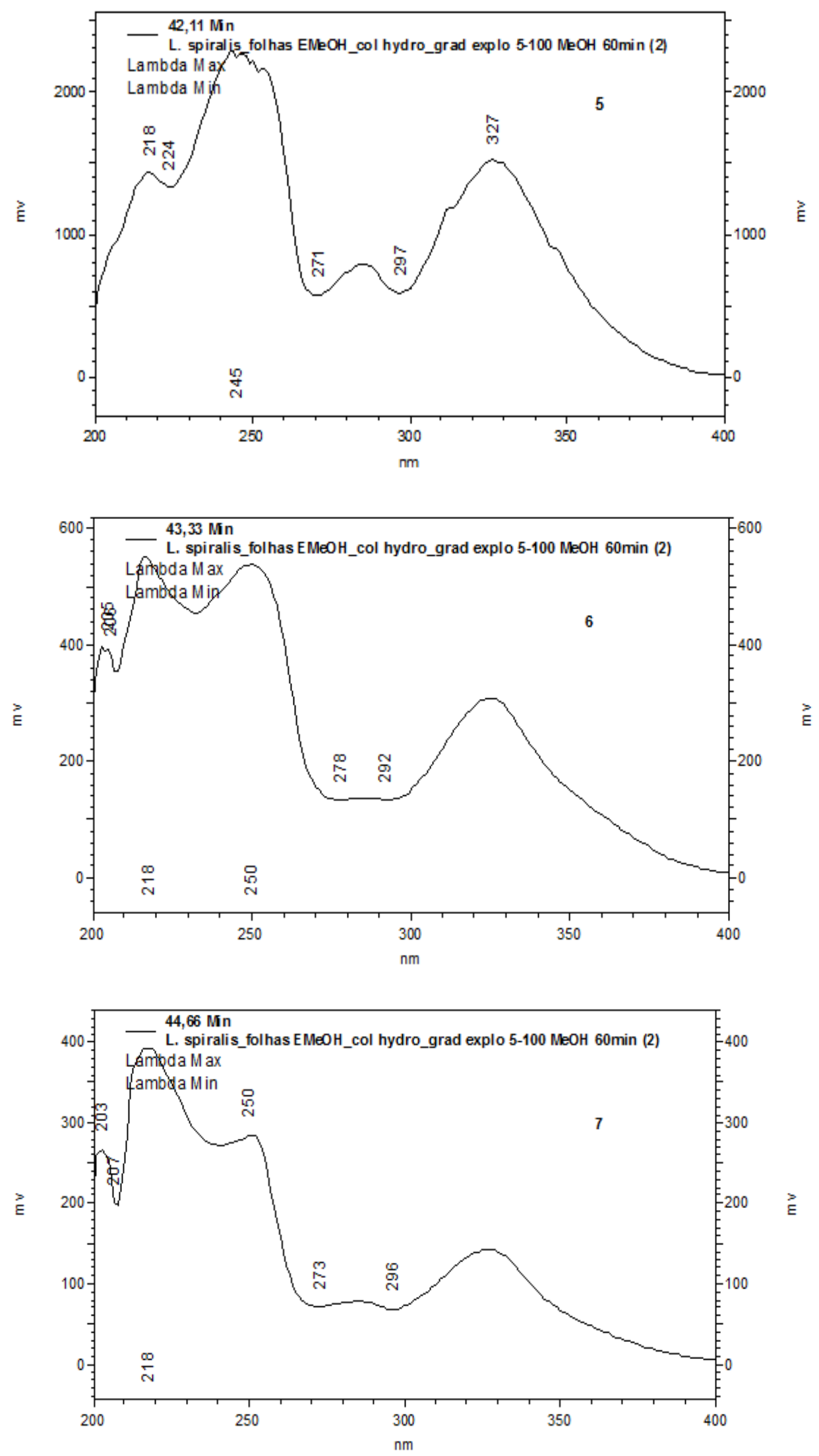


\subsection{Total Flavonoids}

The total flavonoid content was calculated based on the luteolin analytical curve and the percentage composition of flavonoid in the extract was $19.26 \pm 0.04 \%$. These results indicate the presence of significant amounts of that class of phenols.

\subsection{ABTS Radical Cation Scavenging Activity}

Table 1 shows the concentrations of the extract needed to decrease the initial ABTS (2,2'-azinobis-(3-ethylbenzothiazoline-6-sulfonic acid)) concentration by $50 \% \quad(50 \%$ Inhibitory Concentration, $\mathrm{IC}_{50}$ ). The antioxidant activity of the extracts was expressed in quercetin and luteolin equivalents by comparing $\mathrm{IC}_{50}$ of the extracts with $\mathrm{IC}_{50}$ of standards. The $\mathrm{IC}_{50}$ value of the extract showed significant antioxidant activity when compared to standard quercetin and luteolin.

Table 1. 50\% Inhibitory Concentration $\left(\mathrm{IC}_{50}\right)$ values of extract and standards obtained in the ABTS (2,2'-azinobis-(3-ethylbenzothiazoline-6-sulfonic acid)) radical test.

\begin{tabular}{cc}
\hline \multirow{2}{*}{ Samples } & IC $_{\mathbf{5 0}}{ }^{\mathbf{a}}$ \\
\cline { 2 - 2 } & Means \pm SD $^{\mathrm{b}}$ \\
\hline L. spiralis leaves & $1.743 \pm 0.063^{\mathrm{b}}$ \\
quercetin & $1.140 \pm 0.038^{\mathrm{b}}$ \\
luteolin & $1.215 \pm 0.031^{\mathrm{b}}$ \\
\hline
\end{tabular}

${ }^{\mathrm{a}}$ Values in $\mu \mathrm{g} / \mathrm{mL} ;{ }^{\mathrm{b}}<0.001$; SD: standard deviation.

\subsection{Antibacterial and Antifungal Susceptibility}

The results of minimal inhibitory concentration (MIC) determinations of the antimicrobial activity (Table 2) showed noticeable MIC values for the methanolic extract of leaves from $L$. spiralis, against Candida species and Gram-positive bacteria. Luteolin showed activity against all microorganisms tested. The results of minimal fungicidal concentration (MFC) determination indicated that the fungicidal effect of the extract on the studied microorganisms could be expected. A close look at MFC and MIC values revealed that most MFC values correspond to MIC values.

Table 2. Antibacterial and antifungal activity of the methanolic extract of $L$. spiralis leaves and luteolin. Minimal inhibitory concentration (MIC); minimal bactericidal concentration $(\mathrm{MBC})$; minimal fungicidal concentration (MFC).

\begin{tabular}{|c|c|c|c|c|}
\hline \multirow{2}{*}{ Microorganism } & \multicolumn{2}{|c|}{ L. spiralis } & \multicolumn{2}{|c|}{ Luteolin } \\
\hline & MIC $^{a}$ & $\mathrm{MBC} \mathrm{MFC}^{\mathrm{a}}$ & MIC $^{a}$ & $\mathrm{MBC} \mathrm{MFC}^{\mathrm{a}}$ \\
\hline C. albicans & 500 & 1000 & 125 & 500 \\
\hline C. krusei & 500 & 1000 & 250 & 250 \\
\hline C. parapsilosis & 250 & 250 & 125 & 125 \\
\hline C. tropicalis & 1000 & 1000 & 250 & 250 \\
\hline S. aureus & 1000 & 1000 & 125 & 125 \\
\hline B. subtilis & 1000 & 1000 & 62.5 & 125 \\
\hline E. faecalis & 500 & - & 31.25 & 125 \\
\hline
\end{tabular}


Table 2. Cont.

\begin{tabular}{llllc}
\hline Microorganism & MIC $^{\text {a }}$ & $\begin{array}{c}\text { L. spiralis } \\
\text { MBC/MFC }^{\text {a }}\end{array}$ & MIC $^{\text {a }}$ & $\begin{array}{c}\text { Luteolin } \\
\text { MBC/MFC }^{\text {a }}\end{array}$ \\
\hline E. coli & - & - & 250 & 250 \\
P. aeruginosa & - & - & 62.5 & 250 \\
S. setubal & - & - & 250 & - \\
\hline
\end{tabular}

${ }^{\mathrm{a}}$ Values of minimal inhibitory concentration given as $\mu \mathrm{g} / \mathrm{mL} ;(-)>1000 \mu \mathrm{g} / \mathrm{mL}$.

\subsection{Inhibition of Hyphal Formation}

C. albicans cells were incubated for 12 and $24 \mathrm{~h}$ in the presence of three concentrations of extract based on MIC values to C. albicans, and anphotericin B (ANF) at $5 \mathrm{mg} / \mathrm{L}$ as positive control, and then observed under an inverted light microscope (Figure 3). In the absence of the drugs, hyphal formation was observed, while in the presence of the highest concentration of extract tested, hyphal formation of C. albicans was significantly inhibited. The different concentrations of luteolin were not able to inhibit hyphal formation.

Figure 3. Hyphal formation of C. albicans NCPF 3153 cells. (A) 12 h normal growth; (B) $24 \mathrm{~h}$ normal growth; (C) C. albicans cells treated with $0.005 \mathrm{mg} / \mathrm{mL}$ anphotericin $\mathrm{B}$ (ANF) as the positive control; Hyphal formation of $C$. albicans cells was obviously inhibited by the extract at (D) $1 \mathrm{mg} / \mathrm{mL}$; (E) $0.5 \mathrm{mg} / \mathrm{mL}$; (F) $0.25 \mathrm{mg} / \mathrm{mL}$ at $12 \mathrm{~h}$; and (G) $1 \mathrm{mg} / \mathrm{mL}$; (H) $0.5 \mathrm{mg} / \mathrm{mL}$; (I) $0.25 \mathrm{mg} / \mathrm{mL}$ at $24 \mathrm{~h}$. Luteolin did not inhibit the hyphal formation $(\mathbf{J}) 0.25 \mathrm{mg} / \mathrm{mL}$; (K) $0.125 \mathrm{mg} / \mathrm{mL}$; (L) $0.062 \mathrm{mg} / \mathrm{mL}$ at $12 \mathrm{~h}$; (M) $0.25 \mathrm{mg} / \mathrm{mL}$; (N) $0.125 \mathrm{mg} / \mathrm{mL}$; (O) $0.062 \mathrm{mg} / \mathrm{mL}$ at $24 \mathrm{~h}$, compared with (A) and (B). The black bar represents a length of $50 \mu \mathrm{m}$.
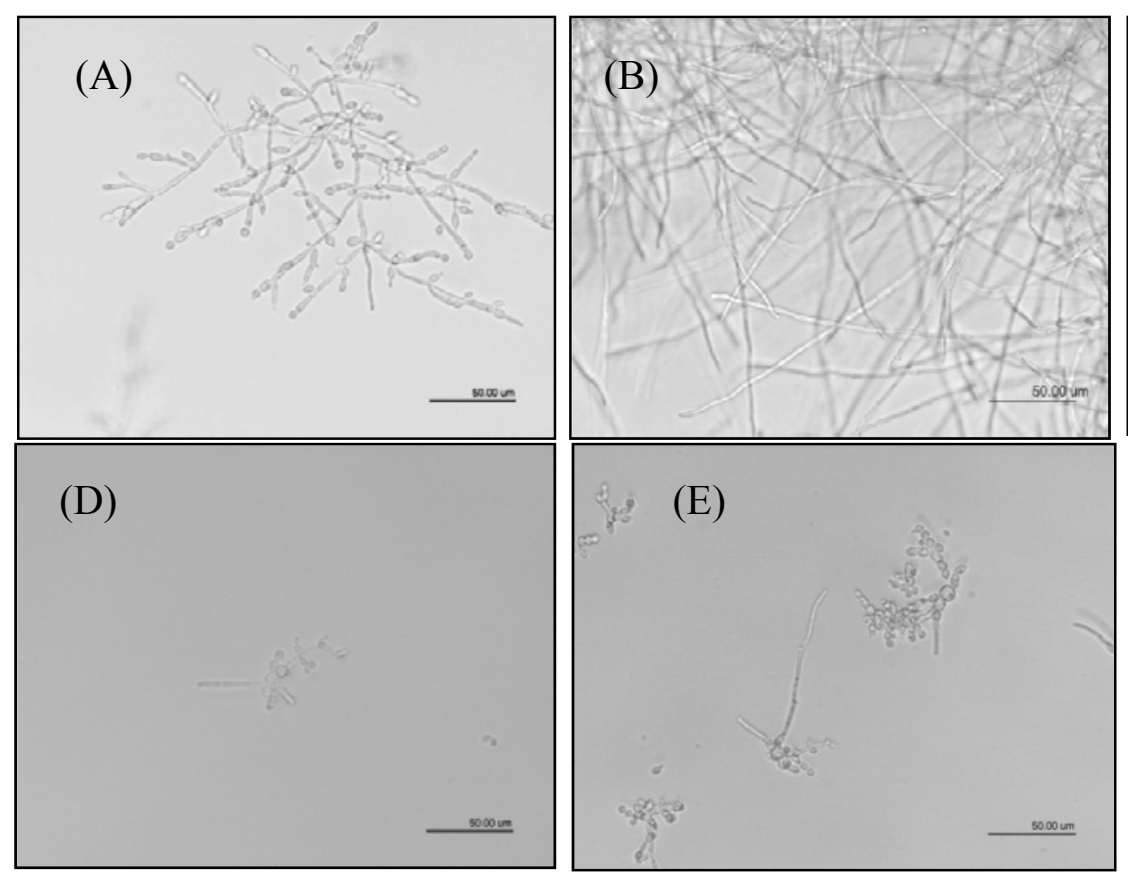

(C) 
Figure 3. Cont.

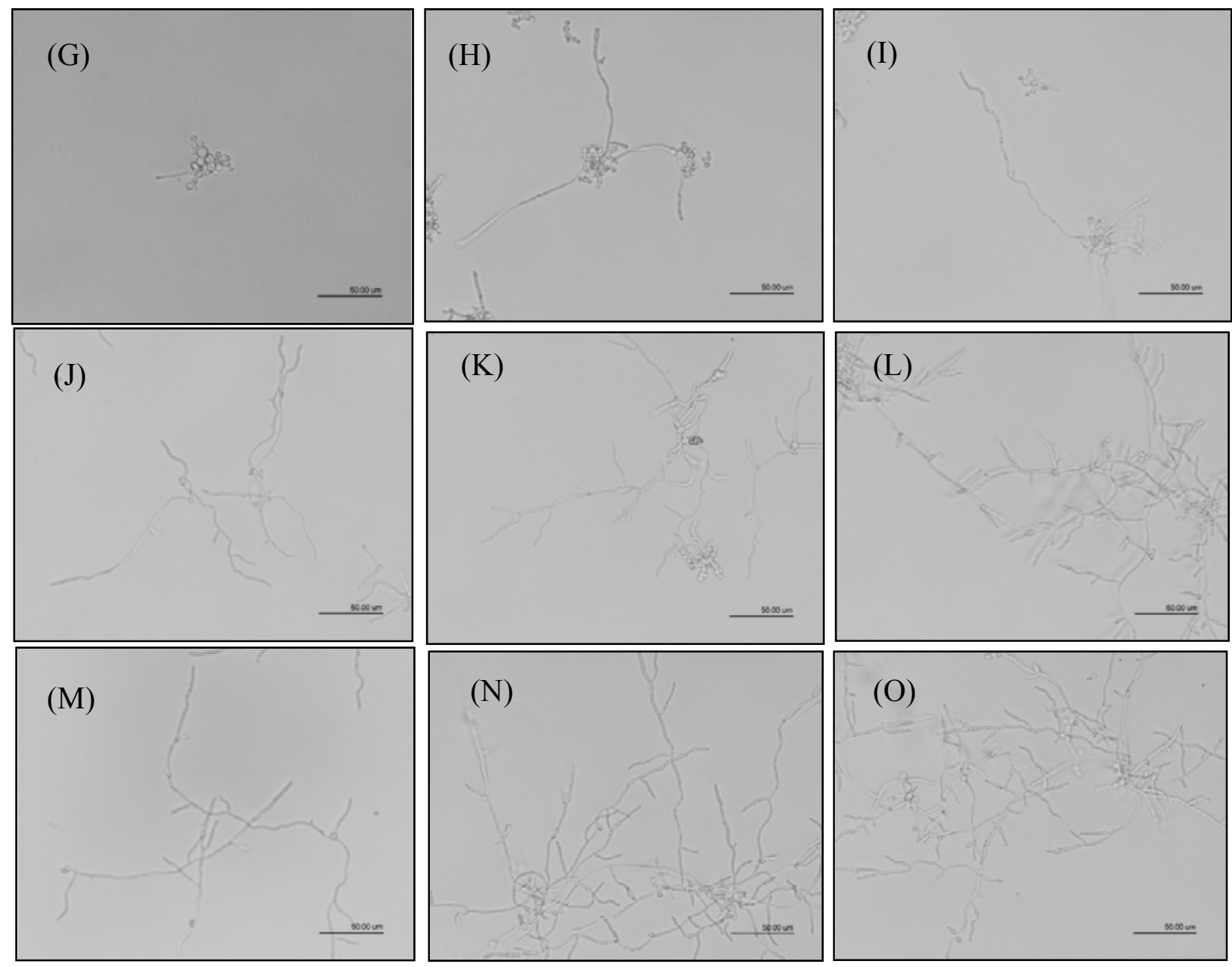

\subsection{MTT and LDH Cell Viability}

Figure 4 shows the effect of the extract on the cell viability of human cervical adenocarcinoma cells line (HeLa cells) after a $24 \mathrm{~h}$ incubation period. Luteolin significantly inhibited cell growth at the tested concentration $(p<0.05)$, and cell viability was affected by the extract treatment at 500 and $1000 \mathrm{mg} / \mathrm{mL}$ when compared with untreated cells. Cell injury was quantitatively assessed by the measurement of lactate dehydrogenase (LDH) release. After a $24 \mathrm{~h}$ incubation period, luteolin and the treatment with different extract concentrations significantly increased cell LDH release $(p<0.05)$, when compared with the untreated control. 
Figure 4. Effect of extract on cell viability and LDH release in cultured HeLa cells. Cells were treated with different concentrations of extract, and luteolin $(31 \mathrm{mg} / \mathrm{L})$ was used as positive control.* Significantly different from the basal conditions.
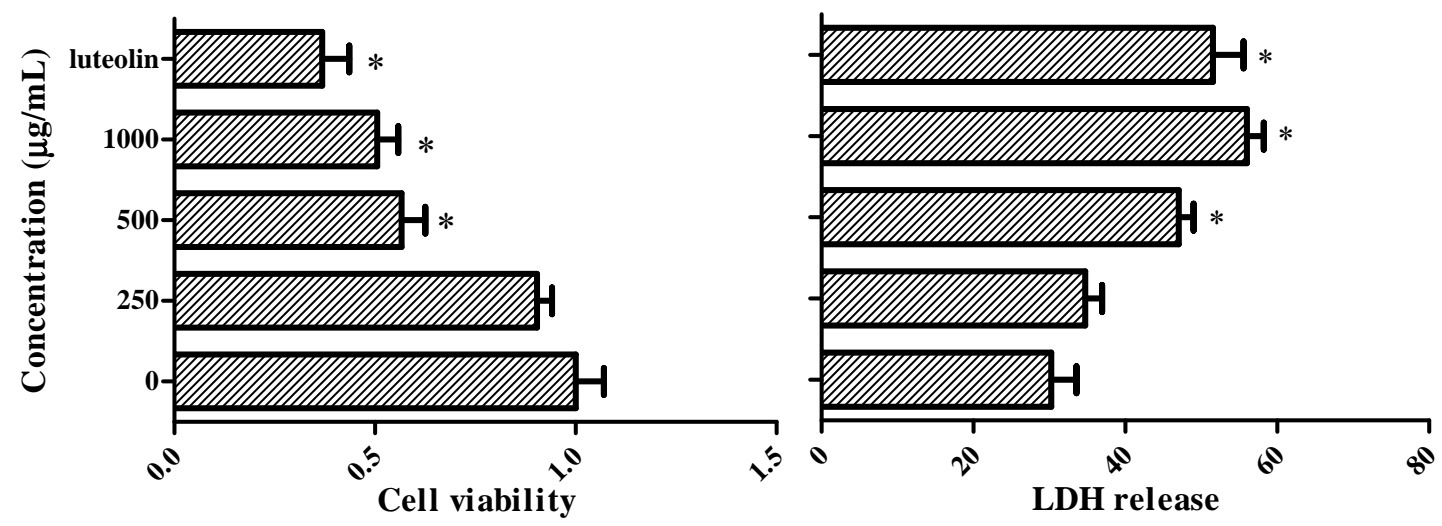

\subsection{Hemolytic Assay}

Figures 5,6 show the hemolytic activity of the extract investigated by measuring the lysis of a $10 \%(\mathrm{v} / \mathrm{v})$ human red blood cells suspension in a spectrophotometric assay. In this experiment, Triton X-100 1\% ( $/ \mathrm{v})$ was used as a positive control and induced $95.0 \pm 3.1 \%$ of red blood cell lysis. The extract and luteolin showed no significant effect on red blood cells lysis.

Figure 5. Hemolytic activity of extract of leaves of L. spiralis. Extract (filled circle) and positive control Triton X-100 (open circle).

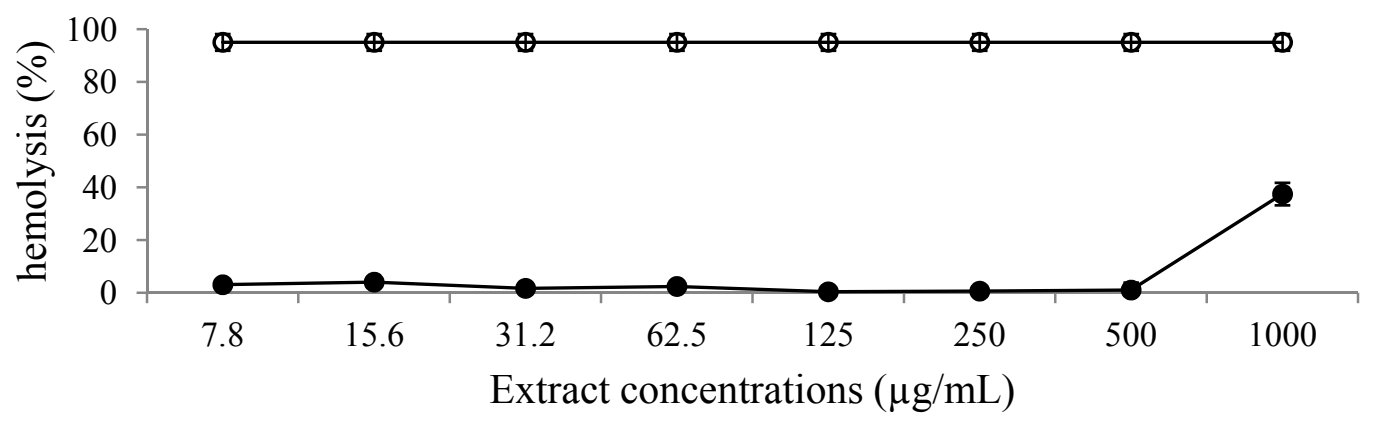

Figure 6. Hemolytic activity of luteolin. Luteolin (filled circle) and positive control Triton X-100 (open circle).

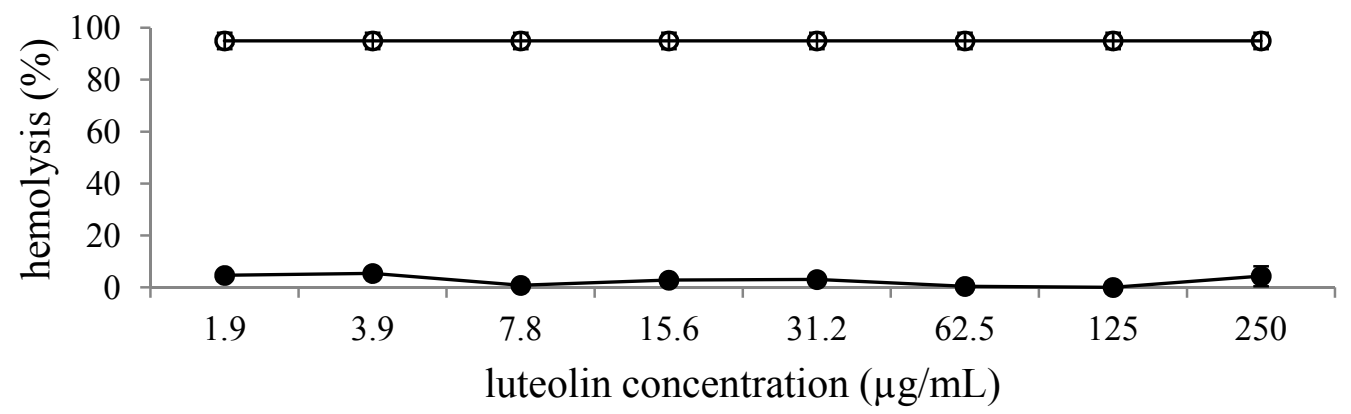


ROS and free radicals such as superoxide anion, hydrogen peroxide and hydroxyl radicals are considered to be implicated in degenerative processes related to aging, cancer and atherosclerosis, mainly because they can induce the oxidative damage of cell membranes, DNA, and proteins [17]. Thus, blocking the generation of ROS and free radicals by supplementation of antioxidants might have a beneficial role in preventing these free radical-related diseases. Several studies have shown that phenolics are the bioactive compounds that offer more benefits to human health and many authors have reported a direct relationship between total phenolic content and antioxidant activity in numerous seeds, fruits and vegetables [18-20]. As expected, methanolic extract obtained from leaves of L. spiralis presented high flavonoid content. This fact correlates with the remarkable differences in the polarity of the extraction solvents used and the solubility of phenolic compounds in them. In fact, methanol (polar solvent) is considered one of the best solvents for phenolic extraction. The chemical analysis of the extract by HPLC-PAD confirmed the presence of flavonoids as the major secondary metabolite compounds in leaves of $L$. spiralis. The features of the UV spectra with bands of maximum of absorption at 239-250 (Band II) $\mathrm{nm}$ and 327-349 (Band I) nm suggested the presence of flavones [16]. Some authors studied the contents of soluble phenolic compounds of the capitula of 21 species of Leiothrix. The presence of luteolin $O$ - and $C$-glucopyranoside was determined in Leiothrix species [13] and another study verified the presence of xanthones and flavone with antioxidant activity in capitula of L. flavescens and L. curvifolia [14]. In agreement, in this study the $\mathrm{IC}_{50}$ values of methanolic extract obtained from the ABTS assay were significantly correlated with the total flavonoid standards, suggesting that flavonoids in these extracts constitute an important portion of the antioxidant activity.

It was suggested that antioxidant capacity of $L$. spiralis was mainly due to the presence of luteolin derivatives. Multiple mechanisms may underlie the antioxidant effect of luteolin. Luteolin functions as a ROS scavenger through its own oxidation and possesses the essential structures to antioxidant activity of flavonoids: 3',4'-hydroxylation, the presence of a double bond between carbons 2 and 3 and a carbonyl group on carbon 4 . The hydrogen atom from an aromatic hydroxyl group can be donated to free radicals. As an aromatic compound, luteolin can support unpaired electrons around the electron system. Moreover, luteolin inhibits ROS generating oxidases and may directly inhibit enzymes that catalyze the oxidation of cellular components [21].

Flavonoids exhibit inhibitory effects against multiple microorganisms. The antimicrobial actions result from an interaction between these compounds and the cell membrane of the target microorganisms, probably due to their ability to bind with extracellular and soluble proteins and also with cell walls [22]. In this study, the extract showed antimicrobial activities against Gram-positive organisms. These differences may be attributed to the fact that the cell wall in Gram-positive bacteria is of a single layer, whereas the Gram negative cell wall is a multilayered structure. This tendency could be explained by the fact that Gram negative bacteria possess an outer membrane surrounding the cell wall, which restricts diffusion of bioactive compounds due to the presence of lipopolysaccharide [23]. However, phenolic compounds maybe not only affect bacterial membranes but also mammalian cells such as erythrocytes [24]. They can interact with membrane lipids and proteins of erythrocytes and result in membrane damage [25]. The in vitro toxicity on the red blood cell membrane of various plant extracts has been studied and correlated with their constituents. The extract and luteolin showed very low hemolytic activity against human blood cells. On the other hand, flavonoids have been revealed to protect biological membranes against free radical-induced oxidative damage. They scavenge reactive 
oxygen species and, in some cases, their interaction with cellular proteins has been suggested, especially with heme proteins, which exert their physiological functions by the oxidation and reduction of heme iron [26-28].

In a previous work, chemical fractionation of the methanolic extract of leaves of $L$. spiralis Ruhland afforded the flavonoids luteolin-derivatives and xanthones with antimicrobial activity [15]. The methanolic extract of leaves from $L$. spiralis as well as the flavonoid luteolin, showed activity against all Candida species tested. C. albicans is a dimorphic yeast and its ability to switch from yeast cells to hyphae is considered to be important for the interactions of C. albicans with its host. Hyphae are an important factor of fungal virulence. It is through hyphae that C. albicans invades human tissues [29]. The microscopy observations showed that extract at a concentration of $1000 \mu \mathrm{g} / \mathrm{mL}$ clearly inhibited hyphal formation during the hyphal induction of $C$. albicans. This result is important to characterize the action of the extract on the yeast tested. The antifungal activity of the phenolic compounds has been attributed to their lipophilic properties, which determine their ability to penetrate into the plasma membrane and induce changes in the physicochemical properties of the cell wall, cell membrane, and cellular organelles [30]. Antioxidant activity may be important in the antifungal mode of action of phenolic compounds. A hypothesis is that during stress, fungi respond by controlling secondary metabolite production and authors have also linked the antioxidant activity of phenolic compounds to their activity on metabolites biosynthesis [31-32].

The human body possesses multiple endogenous systems to protect cellular molecules against the oxygen radical-induced damage. These defense mechanisms include antioxidative enzymes, such as superoxide dismutase (SOD); catalase; and glutathione peroxidase [33]. Mammalian cell culture and cell-free studies have begun to elucidate the underlying mechanisms of the potential protective effects of plant constituents against carcinogenesis, including antimutagenic effects of extracts and natural compounds against cancer inducing agents. Cells are very susceptible to mild oxidation, for example, with dilute solutions of hydrogen peroxide. These changes can be protected by additions of various antioxidant compounds such as flavonoids. Therefore, it is possible to speculate that flavonoids should offer cancer protection via their antioxidant properties [34].

Antioxidant activity is involved in cancer prevention at the initiation stage while antiproliferative activity is targeting cancer cells at the promotion and progression stages. However, it should be noted that by using the MTT-assay, it is not possible to differentiate between cell growth inhibition and an increase in cell death [35]. In the meantime, the LDH leakage assay revealed toxicity after exposure at the same concentrations, therefore, the extract has promoted rupture of the cell membrane in HeLa cells. In this regard, data from studies focusing on the elucidation of the molecular basis of the putative anticancer activity of polyphenols indicate that both, the inhibition of cell growth and the induction of cell death, play a role in the antitumor activity of polyphenols [35-37]. Furthermore, data from other cell culture studies strongly suggest that the mechanism whereby phenolic compounds modulate cell proliferation is remarkably dose-dependent [21-38]. Interestingly, the arrest of HeLa cell growth was evident after a $24 \mathrm{~h}$ treatment, with the highest concentration used. This indicates that the polyphenols in the extract promptly initiated a series of cellular events leading to the inhibition of cell proliferation and/or the induction of cell death. 


\section{Experimental Section}

\subsection{Plant Material}

Leaves of L. spiralis (Bong.) Ruhl. were collected in May 2006 in Diamantina, Minas Gerais State, Brazil, and authenticated by Dr. Paulo Takeo Sano from the Institute of Biosciences of the University of São Paulo (IB-USP), São Paulo. A voucher specimen (SANO $n^{\circ} 4798$ ) was deposited at the Herbarium of the IB-USP. Leaves of $L$. spiralis were oven dried at $45{ }^{\circ} \mathrm{C}$ for one week and powdered separately. The dried leaves of L. spiralis (2.00 g) were powdered and extracted with hexane, methylene chloride, and methanol, successively. The methanol extract (1.2 g) was used for this work. Luteolin was obtained by Sigma ${ }^{\circledR}$.

\subsection{Chemical Characterization of the Extract}

The chromatographic profile of the methanolic extract of the leaves from L. spiralis was obtained by using a Jasco (Tokyo, Japan) liquid chromatograph equipped with a PU-2089 Plus pump, a MD-2010 Plus Photodiodo Array detector (PAD) and a Rheodyne 7725 sample injector with a $20 \mu \mathrm{L}$ sample loop. The analytical column was a Phenomenex Synergi Hydro RP18 $(250 \times 4.6 \mathrm{~mm}$ i.d.; $4 \mu \mathrm{m})$ equipped with a Phenomenex security guard column $(4.0 \times 2.0 \mathrm{~mm}$ i.d. $)$. The mobile phase composition was methanol. The gradient program was as follows: $5 \%-100 \%$ methanol in $60 \mathrm{~min}$. The flow rate was $1.0 \mathrm{~mL} / \mathrm{min}$ and the total run time was $60 \mathrm{~min}$. The software EZChrom Elite 3.17 was used for control analytical system, data collection and processing.

\subsection{Total Flavonoids}

Total flavonoids were estimated according to Georgetti S.R. et al. [39]. To $0.5 \mathrm{~mL}$ of sample, $0.5 \mathrm{~mL}$ of $2 \% \mathrm{AlCl}_{3}$ ethanol solution was added. After $60 \mathrm{~min}$ at room temperature, the absorbance was measured at $351 \mathrm{~nm}$. Total flavonoid contents were calculated as luteolin equivalent from an analytical curve.

\subsection{ABTS Radical Cation Scavenging Activity}

The free radical scavenging activity of the extract was determined by ABTS radical cation decolorization assay [40]. It involved the generation of $\mathrm{ABTS}^{\cdot+}$ chromophore by the oxidation of ABTS with potassium persulfate. The $\mathrm{ABTS}^{\circ+}$ radical cation was generated by reacting ABTS and potassium persulfate after incubation at room temperature in the dark for 12-16 h. The solution was then diluted by mixing $1 \mathrm{~mL} \mathrm{ABTS}^{\cdot+}$ solution with methanol, to obtain an absorbance of about 0.7 at $734 \mathrm{~nm}$ using the spectrophotometer. The reactive mixture (extract in different concentrations and $\mathrm{ABTS}^{\circ+}$ ) was allowed to stand at room temperature for $15 \mathrm{~min}$ and the absorbance was immediately recorded at $734 \mathrm{~nm}$. Quercetin and luteolin standard solutions were prepared and analyzed under the same conditions. The results were expressed as $50 \%$ inhibitory concentration or $\mathrm{IC}_{50}$. 


\subsection{Antimicrobial Activity}

The MIC was determined by the broth microdilution method, according to the standard reference method [41,42]. The antifungal activity was evaluated against C. albicans (ATCC 18804 and NCPF 3153), C. krusei (ATCC 6258), C. parapsilosis (ATCC 22019) and C. tropicalis (ATCC 750) and the antibacterial activity was evaluated against Staphylococcus aureus (ATCC 25923), Bacilus subtillis (ATCC 19659), Enterococcus faecalis (ATCC 29212), Escherichia coli (ATCC 25922), Pseudomonas aeruginosa (ATCC 27853) and Salmonella setubal (ATCC 19196). The extract and luteolin were dissolved in $25 \%$ methanol and water to initial concentration of extract of $1000 \mu \mathrm{g} / \mathrm{mL}$. Then, a two-fold serial dilution was made in order to obtain concentration ranges of $7.8-1000 \mu \mathrm{g} / \mathrm{mL}$. $100 \mu \mathrm{L}$ of each concentration were added to 96-well microplates containing $80 \mu \mathrm{L}$ of RPMI 1640 for yeast and Muller-Hinton broth for bacteria. The inocula of bacteria and yeast were standardized at $1.0 \times 10^{7}$ and $2.5 \times 10^{3} \mathrm{CFU} / \mathrm{mL}$, respectively. Ciprofloxacin, fluconazole and $25 \%$ methanol and water were used as positive and negative control. The plates were incubated at $37{ }^{\circ} \mathrm{C}$ for $24 \mathrm{~h}$ for bacteria and $48 \mathrm{~h}$ for yeast. The assay was repeated three times. The MIC of the samples was detected after the addition $(50 \mu \mathrm{L})$ of resazurin solution $(0.2 \mathrm{mg} / \mathrm{mL})$ for bacteria and $2.0 \%$ triphenyl-tetrazolium chloride (TTC) solution for yeast, and incubated at $37{ }^{\circ} \mathrm{C}$ for $30 \mathrm{~min}$. Growth of bacteria changes the blue dye resazurin to a pink color. The pink color indicates positive growth, and blue indicates growth inhibition. Yeast growth changes the colorless TTC to a red color. MIC was defined as the lowest sample concentration that prevented this change and exhibited inhibition of microorganism growth.

For the determination of minimal bactericidal concentration (MBC) and MFC, a portion from each well that showed antibacterial activity and antifungal activity was plated on Muller-Hinton and Sabouroud agar, and incubated at $37^{\circ} \mathrm{C}$ for $24 \mathrm{~h}$. The lowest concentration that yielded no growth after this sub-culturing was taken as the MBC/MFC [43].

\subsection{Inhibition of Hyphal Growth}

C. albicans (NCPF 3153) cells from a $48 \mathrm{~h}$ stationary phase culture were transferred to microplate with RPMI 1640 medium supplemented with fetal bovine serum (FBS) to a final concentration of $2.5 \times 10^{3} \mathrm{CFU} / \mathrm{mL}$, and extract and luteolin solution were added to the growth medium to final concentrations of $0.5 \times \mathrm{MIC}, 1 \times \mathrm{MIC}$ and $2 \times \mathrm{MIC}$, and the cultures were incubated for 12 and $24 \mathrm{~h}$ at $37{ }^{\circ} \mathrm{C}, 5 \% \mathrm{CO}_{2}$ [44]. The hyphal formation was observed under an inverted light microscope (Nikon TE 2000-U Eclipse) with the magnification of $400 \times$. ANF $(5 \mathrm{mg} / \mathrm{L})$ was used as a positive control.

\subsection{MTT and LDH Cell Viability Assay}

Cell viability was determined by using the conversion of MTT to formazan via mitochondrial oxidation [45]. The human cervical adenocarcinoma cells line (HeLa-ATCC: CCL-2; 5000 cells/well) were treated with the extract and luteolin (0, $0.5 \times \mathrm{MIC}, 1 \times \mathrm{MIC}$ and $2 \times \mathrm{MIC}$ to C. albicans) for $24 \mathrm{~h}$. Then, MTT solution was added to each well at a concentration of $10 \mathrm{mg} / \mathrm{mL}$ and the plates were incubated at $37^{\circ} \mathrm{C}$ for another $4 \mathrm{~h}$. After incubation, $0.2 \mathrm{~mL}$ DMSO was added to each well to dissolve the formazan and the absorbance was read at $570 \mathrm{~nm}$ using a spectrophotometric microplate reader. 
The viability was determined based on a comparison with untreated cells. Luteolin was used as a positive (cytotoxic) control. The experiments were performed in triplicate and repeated at least three times.

Cell injury was quantitatively assessed by the measurement of LDH, released from damaged or destroyed cells, in the extracellular fluid $24 \mathrm{~h}$ after the experiment. An aliquot of bathing media was combined with NADH and pyruvate solutions. LDH activity is proportional to the rate of pyruvate loss. The quantity of LDH released by the cells into the medium was measured by the decrease in the absorbance at $340 \mathrm{~nm}$ for NADH disappearance within different times $(0,1,2$ and $3 \mathrm{~min})$. The difference in absorbance per minute was determined and the average multiplied by the factor (10080).

The results were statistically analyzed by comparing the LDH and MTT values obtained at baseline with those obtained in different treatments by analysis of variance (ANOVA) followed by Dunnett test (multiple comparisons with one control) with $p<0.05$.

\subsection{Hemolytic Assay}

Human erythrocytes from healthy individuals were collected in vacuum tubes containing heparin as anti-coagulant. The erythrocytes were harvested by centrifugation for $10 \mathrm{~min}$ at $2000 \mathrm{rpm}$ and washed three times in phosphate buffered saline (PBS). To the pellet, PBS was added to yield a $10 \%(v / v)$ erythrocytes/PBS suspension. The $10 \%$ suspension was then diluted $1: 10$ in PBS. $0.1 \mathrm{~mL}$ of this suspension was added in triplicate to 96 -well microplates containing $0.1 \mathrm{~mL}$ of extract $(7.8-1000 \mu \mathrm{g} / \mathrm{mL})$ or luteolin $(1.9-250 \mu \mathrm{g} / \mathrm{mL})$ serially diluted in PBS. Total hemolysis was achieved with $1 \%$ Triton $\mathrm{X}-100$. The microplate was incubated for $1 \mathrm{~h}$ at $37{ }^{\circ} \mathrm{C}$ and then centrifuged for $10 \mathrm{~min}$ at $2000 \mathrm{rpm}$. The absorbance of the supernatant was measured spectrophotometrically at $450 \mathrm{~nm}$ [46]. The percentage of hemolysis was calculated and statistically analyzed by analysis of variance (ANOVA) followed by Dunnett test (multiple comparisons with one control) with $p<0.05$.

\section{Conclusions}

The biological activity of a plant extract depends on a complex sum of individual properties including its composition, the existing compound structures, affinity for the target site, survival within the biological system, transport properties, and state of the target organism. In this study, we focused our attention on the relationship between some biological activities and antioxidant properties. The methanolic extract of $L$. spiralis leaves showed a significant antioxidant activity, and an antibacterial, antifungal, non-hemolytic and antiproliferative activity could be demonstrated. A better understanding of how antioxidant plant extracts inhibit microorganism growth and inhibit tumor cell proliferation will allow them to be more efficiently used and perhaps synergistically used with other antimicrobial, antiproliferative agents or their anti-hemolytic activity.

\section{Acknowledgments}

The authors gratefully acknowledge the financial support of the CAPES which provided the fellowship to M.G.F.A. and FAPESP Program which provided the fellowship to F.H and the project grant to L.C.S. The authors extend their appreciation to the CIBICI-CONICET, Argentina, for support and collaboration the work through the research group of C.E.S. 


\section{References}

1. Waris, G.; Ahsan, H. Reactive oxygen species: role in the development of cancer and various chronic conditions. J. Carcinog. 2006, 5, 1-8.

2. Hu, H.; Zhang, Z.; Lei, Z.; Yang, Y.; Sugiura N. Comparative study of antioxidant activity and antiproliferative effect of hot water and ethanol extracts from the mushroom Inonotus obliquus. J. Biosci. Bioeng. 2009, 107, 42-48.

3. Song, J.M.; Lee, K.H.; Seong, B.L. Antiviral effect of catechins in green tea on influenza vírus. Antivir. Res. 2005, 68, 66-74.

4. Cushnie, T.P.T.; Lamb, A.J. Antimicrobial activity of flavonoids. Int. J. Antimicrob. Agents. 2005, 26, 343-356.

5. Silva, M.A.; Cardoso, C.A.L.; Vilegas, W.; Santos, L.C. High-performance liquid chromatographic quantification of flavonoids in Eriocaulaceae species and their antimicrobial activity. Molecules 2009, 14, 4644-4654.

6. Ferguson, P.J.; Kurowska, E.; Freeman, D.J.; Chambers, A.F.; Koropatnick, D.J. A flavonoid fraction from cranberry extract inhibits proliferation of human tumor cell lines. J. Nutr. 2004, 134, 1529-1535.

7. Russo, A.; Cardile, V.; Sanchez, F.; Troncoso, N.; Vanella, A.; Garbarino, J.A. Chilean propolis: antioxidant activity and antiproliferative action in human tumor cell lines. Life Sci. 2004, 76, $545-558$.

8. Boivin, D.; Lamy, S.; Lord-Dufour, S.; Jackson, J.; Beaulieu, E.; Côté, M.; Moghrabi, A.; Barrette, S.; Gingras, D.; Béliveau, R. Antiproliferative and antioxidant activities of common vegetables: A comparative study. Food Chem. 2009, 112, 374-380.

9. $\mathrm{Hu}, \mathrm{W} . ; \mathrm{Yu}, \mathrm{L} . ;$ Wanga, M.H. Antioxidant and antiproliferative properties of water extract from Mahonia bealei (Fort.) Carr. leaves. Food Chem. Toxicol. 2010, 49, 799-806.

10. Rocha-Guzmán, N.E.; Gallegos-Infante, J.A.; Gonzalez-Laredo, R.F.; Reynoso-Camacho, R.; Ramos-Gomez, M.; García-Gasca, T.; Rodríguez-Muñoz, E.; Guzmán-Maldonado, S.H.; Medina-Torres, L.; Luján-García, B.A. Antioxidant activity and genotoxic effect on HeLa cells of phytophenolic compounds from infusions of Quercus resinosa leaves. Food Chem. 2009, 115, $1320-1325$.

11. Sano, P.T. Actinocephalus (Koern.) Sano (Paepalanthus sect. Actinocephalus), a new genus of Eriocaulaceae, and other taxonomic and nomenclatural changes involving Paepalanthus Mart. Taxon. 2004, 53, 99-107.

12. Salatino, A.; Salatino, M.L.; Giulietti, A.M. Contents of soluble phenolic compounds of capitula of Eriocaulaceae. Quim. Nova. 1990, 13, 289-292.

13. Dokkedal, A.L.; Salatino, A. Flavonoids of brazilian species of Leiothrix (Eriocaulacaeae). Biochem. System. Ecol. 1992, 20, 31-32.

14. Santos, L.C.; Piacente, S.; Montoro, P.; Pizza, C.; Vilegas, W. Atividade antioxidante de xantonas isoladas de espécies de Leiothix (Eriocaulaceae). Rev. Bras. Farmacogn. 2003, 13, 67-74.

15. Araújo, M.G.F.; Hilário, F.; Nogueira, L.G.; Vilegas, W.; Santos, L.C.; Bauab, T.M. Chemical constituents of the methanolic extract of leaves of Leiothrix spiralis ruhland and their antimicrobial activity. Molecules 2011, 16, 10479-10490. 
16. Mabry, T.J.; Markham, K.R.; Thomas, M.B. The ultraviolet spectra of flavones and flavonols. In The Systematic Identification of Flavonoids; Mabry, T.J., Markham, K.R., Thomas, M.B., Eds.; Springer-Verlag: New York, USA, 1970; pp: 41-45, 165-166.

17. Cheng, L.X.; Tang, J.J.; Luo, H.; Jin, X.L.; Dai, F.; Yang, J.; Qian, Y.P.; Li, X.Z.; Zhou, B. Antioxidant and antiproliferative activities of hydroxyl-substituted Schiff bases. Bioorg. Med. Chem. Lett. 2010, 20, 2417-2420.

18. Parry, J.; Su, L.; Moore, J.; Cheng, Z.; Luther, M.; Rao, J.N.; Wang, J.Y.; Yu, L. Chemical compositions, antioxidant capacities, and antiproliferative activities of selected seed flours. J. Agr. Food Chem .2006, 54, 3773-3778.

19. Zhang, Y.; Seeram, N.P.; Lee, R.; Feng, L.; Heber, D. Isolation and identification of strawberry phenolics with antioxidant and human cancer cell antiproliferative properties. J. Agr. Food Chem. 2008, 56, 670-675.

20. Yang, J.; Liu, R.H.; Halim, L. Antioxidant and antiproliferative activities of common edible nut seeds. Food Sci. Technol. 2009, 42, 1-8.

21. Lin, Y.; Shi, R.; Wang, X.; Shen, H-M. Luteolin, a flavonoid with potentials for cancer prevention and therapy. Curr. Cancer Drug Targets .2008, 8, 634-646.

22. Cowan, N.M. Plant products as antimicrobial agents. Clin. Microbiol. Rev. 1999, 12, 564-582.

23. Burt, S. Essential oils: Their antibacterial properties and potential applications in foods-A review. Int. J. Food Microbiol. .2004, 94, 223-253.

24. Tamaki, M.; Imazeki, Y.; Shirane, A.; Fujinuma, K.; Shindo, M.; Kimura, M.; Uchida, Y. Novel gratisin derivatives with high antimicrobial activity and low hemolytic activity. Bioorg. Med. Chem. Lett. 2011, 21, 440-443.

25. Singh, R.P.; Kaur, G. Hemolytic activity of aqueous extract of Livistona chinensis fruits. Food Chem. Toxicol. 2008, 46, 553-556.

26. Kitagawa, S.; Sakamoto, H.; Tano, H. Inhibitory Effects of Flavonoids on Free Radical-Induced Hemolysis and Their Oxidative Effects on Hemoglobin. Chem Pharm Bull 2004, 52, 999-1001.

27. Asgary, S.; Naderi, G.H.; Askari, N. Protective effect of flavonoids against red blood cell hemolysis by free radicals. Exp. Clin. Cardiol. 2005, 10, 88-90.

28. Blasa, M.; Candiracci, M.; Accorsi, A.; Piacentini, M.P.; Piatti, E. Honey flavonoids as protection agents against oxidative damage to human red blood cells. Food Chem. 2007, 104, 1635-1640.

29. Yang, Y.L. Virulence factors of Candida species. J. Microbiol. Immunol. Infect. 2003, 36, 223-228.

30. Knobloch, E.; Pauli, A.; Iberl, B.; Wies, N.; Weigand, H. Mode of action of essential oil components on whole cells of bacteria-and fungi in plate tests. In Bioflavour: Analyses, Biochemistry, Biotechnology; Schreier, P., Ed. Walter de Gruyter: Berlin, Germany, 1988; pp: 287-299.

31. Dambolena, J.S.; Zunino, M.P.; López, A.G.; Rubinstein, H.R.; Zygadlo, J.A.; Mwangi, J.W.; Thoithi, G.N.; Kibwage, I.O.; Mwalukumbi, J.M.; Kariuki S.T. Essential oils composition of Ocimum basilicum L. and Ocimum gratissimum L. from Kenya and their inhibitory effects on growth and fumonisin production by Fusarium verticillioides. Inn. Food. Sci. Emerging. Technol. 2010, 11, 410-414. 
32. Dambolena, J.S.; Zygadlo, J.A.; Rubinstein, H.R. Antifumonisin activity of natural phenolic compounds. A structure-property-activity relationship study. Int. J. Food Microbiol. 2011, 145, 140-146.

33. Lassen, N.; Black, W.J.; Estey, T.; Vasiliou, V. The role of corneal crystallins in the cellular defense mechanisms against oxidative stress. Semin. Cell. Dev. Biol. 2008, 19, 100-112.

34. Cutter, H.; Wu, L-Y.; Kim, C.; Morre, D.J.; Morre, D.M. Is the cancer protective effect correlated with growth inhibitions by green tea (-)-epigallocatechin gallate mediated through an antioxidant mechanism? Cancer Lett. 2001, 162, 149-154.

35. García-Alonso, J.; Ros, G.; Periago, M.J. Antiproliferative and cytoprotective activities of a phenolic-rich juice in HepG2 cells. Food Res. Int. 2006, 39, 982-991.

36. Luo, W.; Zhao, M.; Yang, B.; Ren, J.; Shen, G.; Rao, G. Antioxidant and antiproliferative capacities of phenolics purified from Phyllanthus emblica L. fruit. Food Chem. 2011, 126, 277-282.

37. Lazzè, M.C.; Savio, M.; Pizzala, R.; Cazzalini, O.; Perucca, P.; Scovassi, A.I.; Stivala, L.A.; Bianchi, L. Anthocyanins induce cell cycle perturbations and apoptosis in different human cell lines. Carcinogenesis 2004, 25, 1427-1433.

38. Selvendiran, K.; Koga, H.; Ueno, T.; Yoshida, T.; Maeyama, M.; Torimura, T.; Yano, H.; Kojiro, M.; Sata, M. Luteolin Promotes Degradation in Signal Transducer and Activator of Transcription 3 in Human Hepatoma Cells: An Implication for the Antitumor Potential of Flavonoids. Cancer Res. 2006, 66, 4826-4834.

39. Georgetti, S.R.; Casagrande, R.; Vicentini, F.T.M.C.; Verri, W.A., Jr.; Fonseca, M.J.V. Evaluation of the antioxidant activity of soybean extract by different in vitro methods and investigation of this activity after its incorporation in topical formulations. Eur. J. Pharm. Biopharm. 2006, 64, 99-106.

40. Re, R.; Pellegrini, N.; Proteggente, A.; Pannala, A.; Yang, M.; Rice-Evans, C. Antioxidant activity applying an improved ABTS radical cation decolorization assay. Free Radical. Biol. Med. 1999, 26, 1231-1237.

41. Rex, J.H.; Alexander, B.D.; Andes, D.; Arthington-Skaggs, B.; Brown, S.D.; Chaturvedi, V.; Ghannoum, M.A.; Espinel-Ingroff, A.; Knapp, C.C.; Ostrosky-Zeichner, L., et al. Reference Method for Broth Dilution Antifungal Susceptibility Testing of Yeasts: Approved Standard, 3rd ed; CLSI document M27-A3 (ISBN 1-56238-666-2). Clinical and Laboratory Standards Institute (CLSI): Wayne, PA, USA, 2002.

42. Wikler, M.A.; Hindler, J.F.; Cockerill, F.R.; Patel, J.B.; Bush, K.; Powell, M.; Dudley, M.N.; Turnidge, J.D.; Elopoulos, G.M.; Weinstein, M.P.; et al. Methods for Dilution Antimicrobial Susceptibility Tests for Bacteria that Grow Aerobically; Approved Standard, 8th ed; CLSI document M07-A8 (ISBN 1-56238-689-1). Clinical and Laboratory Standards Institute: Wayne, PA, USA, 2008.

43. Kuete, V.; Nanab, F.; Ngamenic, B.; Mbaveng, A.T.; Keumedjio, F.; Ngadjuib, B.T. Antimicrobial activity of the crude extract, fractions and compounds from stem bark of Ficus ovata (Moraceae). J. Ethnopharmacol. 2009, 124, 556-561. 
44. Zhang, J.D.; Xu, Z.; Cao, Y.B.; Chen, H.S.; Yan, L.; An, M.M.; Gao, P.H.; Wang, Y.; Jia, X.M.; Jiang, Y.Y. Antifungal activities and action mechanisms of compounds from Tribulus terrestris L. J. Ethnopharmacol. 2006, 103, 76-84.

45. Ding, W.J.; Hasegawa, T.; Peng, D.; Hosaka, H.; Seko, Y. Preliminary investigation on the cytotoxicity of tellurite to cultured HeLa cells. J. Trace. Elem. Med. Biol. 2002, 16, 99-102.

46. He, M.; Du, M.; Fan, M.; Bian, Z. In vitro activity of eugenol against Candida albicans biofilms. Mycopathologia 2007, 163, 137-143.

(C) 2012 by the authors; licensee MDPI, Basel, Switzerland. This article is an open access article distributed under the terms and conditions of the Creative Commons Attribution license (http://creativecommons.org/licenses/by/3.0/). 